\title{
THE IMPACT OF FINANCIAL SYSTEM DEVELOPMENT ON ECONOMIC GROWTH OF SPAIN AND GREECE ๑2020 DERKACH T. V.
}

UDC 339.97

JEL: E20; E62; F30; F43; G32

Derkach T. V. The Impact of Financial System Development on Economic Growth of Spain and Greece

The article analyzes the main financial factors affecting the economic growth, as well as the factors that may impede the country's sustainable economic development. The article analyzes the impact of financial sector on economic growth, using the examples of Greece and Spain. Due to the identification of financial factors, that cause the economic development of countries, it is possible to develop a complex of measures to reduce the negative effects of possible financial crises. The experience of the global monetary and financial crisis has largely demonstrated the interconnections between the financial sectors of countries in the world. The identified patterns of Greece and Spain financial system development will allow to develop a complex of measures to prevent financial crises in the future. The article analyzes financial indicators to identify the interdependence of processes occurring in the financial sector and the economies of Greece and Spain. In order to identify key factors affecting the economic growth of the country, it is necessary to conduct a comprehensive analysis of data in dynamics, responding to changes in the financial sector and in the economy as soon as possible. Similarly, the financial sector cannot be viewed in isolation from the global economy. Therefore, both endogenous and exogenous factors must be considered for forecasts and recommendations to achieve sustainable economic growth. The financial factors cited by the author will allow us to take into account the changing nature of the financial sector and to develop public policy under the volatile financial markets. In the future, given these factors, it will be possible to move on to developing a country-specific quantitative model, which in turn, will allow to develop recommendations for individual countries. Taking account of the European Central Bank's experience in establishing and controlling the financial market, we can elaborate recommendations on the transformation of countries financial sector, as well as apply the results obtained to harmonize the economies of the candidate countries for integration into the European Union.

Keywords: financial system, financial factors, economic growth, Greece, Spain, FDI.

DOl: https://doi.org/10.32983/2222-4459-2020-2-42-49

Fig.: 5. Bibl.: 13.

Derkach Tatyana V. - D. Sc. (Economics), Associate Professor, Head of the Department of Management, International Humanitarian University (33 Fontanska Doroha Str., Odesa, 65009, Ukraine)

E-mail: rubinodessa@gmail.com

ORCID: https://orcid.org/0000-0003-1431-7300

УДК 339.97

JEL: E2O; E62; F30; F43; G32

Деркач Т. В. Вплив розвитку фінансової системи на економічне зростання Іспанії та Греції

У статті аналізуються основні фінансові чинники, що впливають на економічне зростання, а також чинники, які можуть перешкоджати сталому економічному розвитку країни. На прикладі Греції та Іспанії аналізується вплив фінансового сектора країн на економічне зростання. Завдяки виявленню фінансових чинників, що зумовлюють економічний розвиток країн, можна розробити комплекс заходів для зменшення негативних наслідків від можливих фінансових криз. Досвід світової валютно-фінансової кризи значною мірою показав взаємозв'язки між фінансовими секторами країн у світі. Виявлені закономірності розвитку фінансової системи Греиії та Іспанії дозволять розробити комплекс заходів для запобігання фінансовим кризам у майбутньому. У статті проводиться аналіз фінансових показників з метою виявлення взаємозалежності процесів, що проходять у фінансовому секторі та економіці Греції та Іспанії. 3 метою виявлення ключових факторів, що впливають на економічне зростання держави, необхідно проводити комплексний аналіз даних у динаміці, реагуючи на зміни у фінансовому секторі та в економіці якнайшвидше. Так само неможливо розглядати фінансовий сектор у відриві від глобальної економіки. Отже, необхідно враховувати як ендогенні, так і екзогенні чинники для прогнозів і рекомендацій для стабільного економічного зростання. Фінансові фактори, наведені автором, дозволять враховувати мінливий характер фінансового сектора та розробити державну політику під волатильні фінансові ринки. Надалі, з огляду на ці фактори, можна буде перейти до розробки кількісної моделі, що дозволить розробити якісні рекомендації для кожної конкретної країни. 3 огляду на досвід Європейського центрального банку з побудови та контролю фінансового ринку, можна розробити рекомендації по трансформації фінансового сектора країн, а також застосовувати отримані результати для гармонізації економік країн - кандидатів на вступ до Європейського Союзу.

Ключові слова: фінансова система, фінансові фактори, економічне зростання, Греція, Іспанія, ПІІ.

Рис.: 5. Бібл.: 13.

Деркач Тетяна Вадимівна - доктор економічних наук, доцент, завідувачка кафедри менеджмента, Міжнародний гуманітарний університет (вул. Фонтанська дорога, 33, Одеса, 65009, Україна)

E-mail: rubinodessa@gmail.com

ORCID: https://orcid.org/0000-0003-1431-7300

УДК 339.97

JEL: E20; E62; F30; F43; G32

Деркач Т. В. Влияние развития финансовой системы на экономический рост Испании и Греции

В статье анализируются основные финансовые факторы, влияющие на экономический рост, а также факторы, которые могут препятствовать устойчивому экономическому развитию страны. На примере Греции и Испании анализируется влияние финансового сектора стран на экономический рост. Благодаря выявлению финансовых факторов, обусловливающих экономическое развитие стран, можно разработать комплекс мер для уменьшения негативных последствий от возможных финансовых кризисов. Опыт мирового валютно-финансового кризиса в значительной степени показал взаимосвязь между финансовыми секторами стран в мире. Выявленные закономерности развития финансовой систе- 
мы Греции и Испании позволят разработать комплекс мер для предотвращения финансовых кризисов в будущем. В статье проводится анализ финансовых показателей с целью выявления взаимозависимости процессов, проходящих в финансовом секторе и экономике Греции и Испании. С целью выявления ключевых факторов, влияющих на экономический рост государства, необходимо проводить комплексный анализ данных в динамике, реагируя на изменения в финансовом секторе и в экономике как можно быстрее. Также невозможно рассматривать финансовый сектор в отрыве от глобальной экономики. Следовательно, необходимо учитывать как эндогенные, так и экзогенные факторы для прогнозов и рекомендаций для стабильного экономического роста. Финансовые факторы, приведенные автором, позволят учитывать изменчивый характер финансового сектора и разработать государственную политику под волатильные финансовые рынки. В дальнейшем, учитывая эти факторы, можно будет перейти к разработке количественной модели, что позволит разработать качественные рекомендации для каждой конкретной страны. Учитывая опыт Европейского центрального банка в построении и контроле финансового рынка, можно разработать рекомендации по трансрормации финансового сектора стран, а также применять полученные результаты для гармонизации экономик стран - кандидатов на вступление в Европейский Союз.

Ключевые слова: финансовая система, финансовые факторы, экономический рост, Греция, Испания, ПИИ.

Рис.: 5. Библ.: 13.

Деркач Татьяна Вадимовна - доктор экономических наук, доцент, заведующая кафедрой менеджента, Международный гуманитарный университет (ул. Фонтанская дорога, 33, Одесса, 65009, Украина)

E-mail: rubinodessa@gmail.com

ORCID: https://orcid.org/0000-0003-1431-7300

$\mathrm{T}$ The financial system plays an important role in the development of the national economy as an intermediary for mobilization and allocation of capital, economic resources and especially as a payment service provider. A stable financial system is the key factor in ensuring sustainable economic development.

Recent experience of different countries shows that just as the development of the financial sector can stimulate economic growth, financial fragility and imbalance can seriously hinder the growth. The main challenge for the vast majority of countries was choosing the right way to reform the financial sector and its positioning in the proper institutional environment.

After the global financial crisis of 2008-2009, the economies of Greece and Spain suffered significant losses due to considerable amounts of financial debt. In this regard, methods of comparative assessment of financial systems and possible forecasting of further financial system development are becoming crucially relevant.

Issues related to analysis of financial systems are considered in research works of authors from different countries of the world including A. Demirguk-Kunt, R. Levine, C. V. Paun, P. Hugh, L. Blanco, O. E. Ergungor, L. Gambacorta, J. Yang, K. M. Guei, B. Gadanecz, and others. The statistical analysis is based on the data gathered from UNCTAD Statistics (1990-2018).

The aim of the article is determining the essence of the financial system and studying the main factors affecting it; analyzing the impact of financial indicators on the economy of Greece and Spain in the context of globalization of world financial markets.

After the financial crises of the late 1990s, interest in a systematic assessment of strengths and weaknesses of financial systems, with the ultimate goal of elaborating appropriate policies to achieve financial stability and stimulate development of the financial sector, began to grow.

One of the first researchers to study this matter were Asli Demirguk-Kunt and Ross Levin, who used data on 150 countries to analyze the components of financial systems and their impact on each individual country. In their work [1], they apply statistical methods to study financial performance and analyze the size, activity, and effectiveness of financial systems. Moreover, they characterize the influence of banks, other financial institutions and funds on economic stability and consider the income per capita.

Christian Valeriu Paun, Radu Christian Mutescu, Vladimir Mihai Topan and Dan Constantin Danuletiu prove that quality of a financial system (markets, institutions, instruments) affects economic growth. They conclude that sustainable development is strongly influenced by financial markets and institutions. Monetary policy has a considerable impact on the most important economic indicators (interest rates, exchange rates), which are a basis for any economic calculation [2].

$\mathrm{H}$ owever, some scientists express the idea that the development of the financial sector is the result of economic growth. The faster the growth rate of real national income the greater businesses demand for external funds and financial intermediation is. In most circumstances firms will not be able to finance expansion through internally generated funds, so this will lead to excess borrowing [3]. Thus, economic growth causes financial development, but financial development does not always cause economic growth - as stated by Luisa Blanco in her study [4].

Emre Ergungor's alternative approach suggests that the structure of a financial system itself - whether a banking or market one - affects economic growth. Unlike earlier studies, he discovers that there is a non-linear relationship between growth and financial structure [5].

Leonardo Gambacorta, Jing Yang and Kostas Tsatsaronis considered determinants of financial structure and how the structure can affect economic growth. They aimed to reveal the relationship between a country's peculiarities and its financial structure and the relationship between financial structure and economic growth. It was 
found that banks and markets contribute to economic growth in a complementary way. Policies of the central bank aimed at controlling inflation and banking intermediation or deeper development of financial markets also lead to increased economic growth. The research also concerns the role of banks and markets in moderating business cycle fluctuations [6].

An important part of the financial system is foreign direct investment (FDI) [7-9]. Considering the balance between FDI inflows and outflows in Greece and Spain (Fig. 4, Fig. 5), it can be concluded that after the introduction of the euro in Spain the outflow significantly exceeded the inflow. In Greece, on the contrary, the inflow significantly exceeded the outflow, which is due to more attractive conditions for foreign investment.

Considering inflation in these countries, we can see a significant decrease after 2008, although, in 2010, the inflation rate in Greece was expected to be $4.7 \%$ due to the debt crisis and a significant state budget deficit.

In contrast to price stability, it is difficult to determine financial stability: it is necessary to take into account the interdependence and complex interactions of different financial system elements and their interconnections with each other and with the real economy. This is further complicated by the time and cross-border aspect of such interactions.

However, over the last two decades, researchers continued to analyze the conditions of financial stability through various vulnerabilities in the financial system.

$\mathrm{T}$ he European Central Bank (ECB), in its financial stability report, assessed financial risks through focusing on a small number of key indicators. Moreover, ongoing efforts are underway to develop a single approach that could indicate a degree of financial fragility [10].

The approach to developing these financial stability measures has varied from micro to macro dimensions of financial sustainability. From considering early warning indicators, the focus has shifted to a broader systems assessment of risks to the financial markets, institutions and infrastructures. The financial system should be considered as a complex system of factors that are constantly changing.

Financial stability indicators mainly reflect the degree of stability of individual sectors and segments of the financial market or are focused on particular sources of risk. Sector-specific macro indicators may be useful, but they do not describe the system as a whole. For this reason, indices are often used in the literature to capture information obtained using individual macroeconomic, financial and other indicators.

Blaise Gadanecz and Kaushik Jayaram made significant contributions to the development of quantitative measures of financial system sustainability and their use. In their article, they consider the definition of financial sustainability and its importance in identifying key variables. Furthermore, they search for ways to combine these individual variables into indicators to monitor key sectors of the economy. In their study, by using different indicators and creating aggregate indices to better understand financial stability, the authors show that, despite the problems associated with their construction, the aggregate indices have a greater ability to determine the degree of financial stability than individual indicators.

Financial sustainability indicators are statistical measures designed to control and monitor financial health and stability of the financial sector of the country and its corporate and household agents. The main reason of developing this metric system was to make international comparative data about stability of financial systems available for a large number of researchers [11].

$\mathrm{I}$ making such assessments country-specific factors should be taken into account, especially the structure of the country's financial system. Researchers should consider: the number of banks in the economy, whether there are diverse financial intermediaries, whether there is a capacious and liquid securities market, and whether financial intermediaries conduct international operations.

The construction of such system of financial stability indicators is based on the following criteria:

+ coverage of the most important markets and institutions;

+ analytical significance;

+ proved usefulness;

+ relevance to most countries, institutions or crisis situations;

+ accessibility;

+ symmetry of information display at the sectoral level;

+ usage of aggregate information;

+ consolidated approach to avoid double counting of capital and activities [12].

The functioning of the financial system depends on overall economic activity. Financial institutions have a significant impact on certain macroeconomic changes.

Some macroeconomic changes are often preceded by banking crises, so the stability of financial system should consider the complete picture of the macroeconomic situation, in particular, factors that influence the vulnerability of the economy to reversing capital flows and currency crises.

Taking into account these facts, it is possible to distinguish the following indicators of macroeconomic changes or external shocks that may affect the financial system:

1. Aggregate growth. Low or declining overall cost growth rates often weaken the debt service potential of domestic borrowers and increase credit risk. The recession was preceded by many episodes of systemic financial turmoil.

2. Instability in inflation. Such volatility makes accurate assessment of credit and market risks extremely 
difficult. Inflation is often positively correlated with higher price volatility, a factor that increases portfolio risk and erodes financial institutions' information base for planning, investing and evaluating loans.

It is this that led to the application of inflation targeting by the ECB. The trends in inflation rates in the countries under study can be seen in Fig. 1 . ferent countries is often perceived as an indicator of contagion risk. The countries under study belong to the same economies group - PIIGS (an acronym for Portugal, Italy, Ireland, Greece, and Spain, which were the weakest economies in the eurozone during the European debt crisis).

7. Directed lending and investment. For example, a considerable increase in central bank loans to the go-

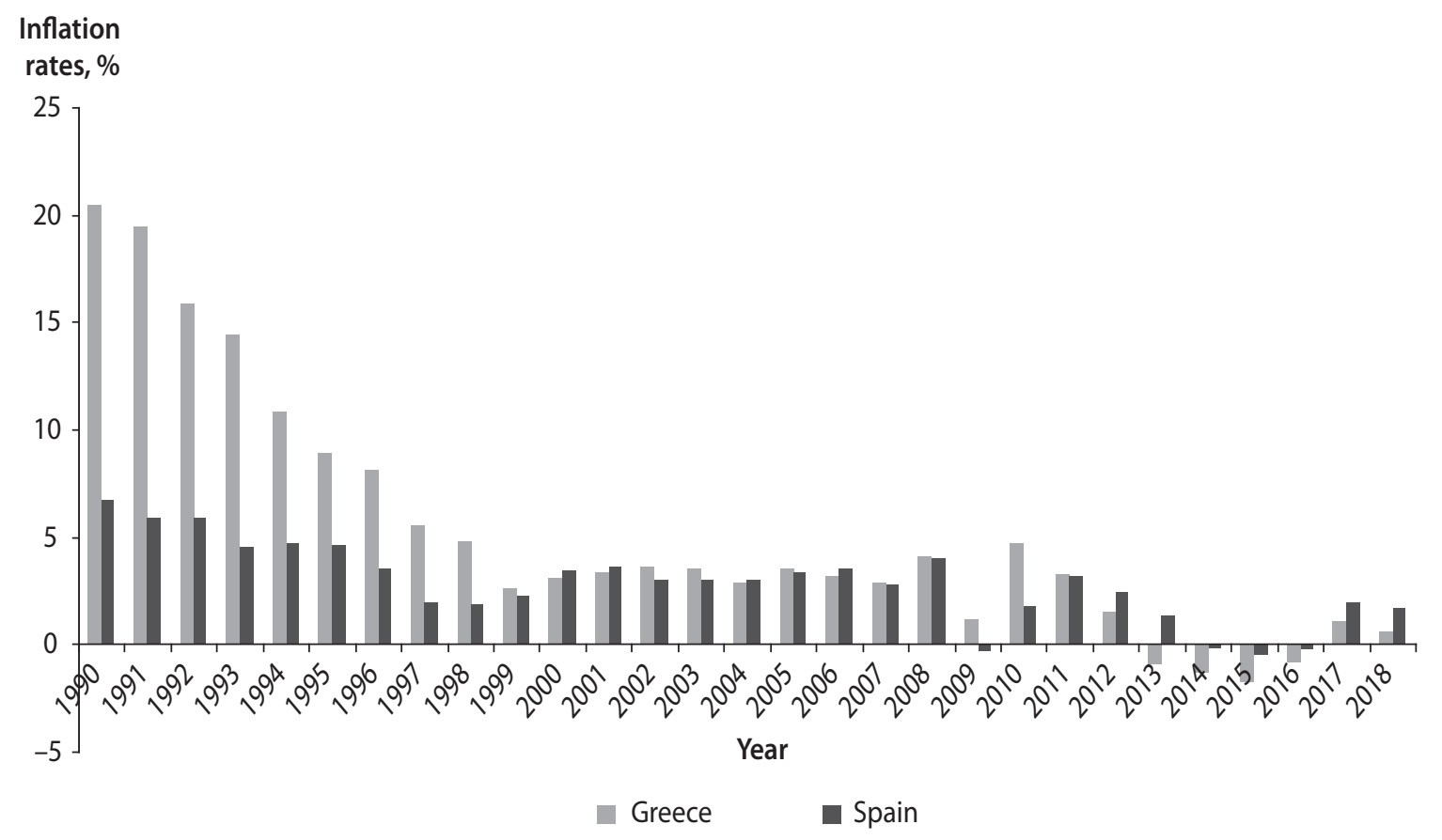

Fig. 1. Inflation rates in Greece and Spain 1990-2018 (\%) [13]

3. Instability of interest rates and foreign exchange rates. The more volatile these rates are, the higher the interest rate and currency risks for financial institutions are. The vulnerability of the financial system will be greater given a higher interference of external debt and greater share of foreign portfolio investment in total foreign investment.

Considering Greece and Spain, it can be stated that the introduction of a single currency, the euro, had a positive impact on the country's economy and, starting from 2002, led to a GDP growth (Fig. 2, Fig. 3).

4. Credit booms (fast growth of the credit-to-GDP ratio). Such booms preceded severe financial crises. A rapid expansion of lending by financial institutions is often due to poor quality analysis of loan applications.

5. As a country's financial system is linked to the systems of other countries through flows of capital markets and bilateral trade, the emergence of financial crises in other countries may lead to a financial crisis or internal problems.

6. Correlation of financial markets. Financial contagion risk increases for countries with similar macroeconomic characteristics or close financial ties (through commercial banks, capital markets or bond loans) with a country in crisis. In particular, the correlation between stock market prices, exchange rates and interest rates in dif- vernment can lead to inflationary pressures and affect the financial system.

8. Debt in the economy. Debt growth should signal difficulties in debt servicing by the government or private sector borrowers. These problems adversely affect solvency and liquidity of financial institutions.

9. Balance of payments indicators. Current account deficit. Increase in the current account deficit-to-GDP ratio is usually associated with large inflows of foreign capital, which are mediated by the internal financial system and can lead to an increase in asset prices and a credit boom.

10. Reserves and external debt. A low ratio of interstate reserves to short-term liabilities is considered, in particular, by investors as the main indicator of vulnerability.

11. Composition and maturity of capital flows. The composition of capital flows can also be a preliminary indicator of potential vulnerability. Countries are particularly vulnerable if their current account deficits are accompanied by low investment ratios or excessive investments.

Financial development contributes to investment, which is an important source of growth, but also promotes more efficient allocation and use of scarce capital resources. Considering FDI flows in the economies of 


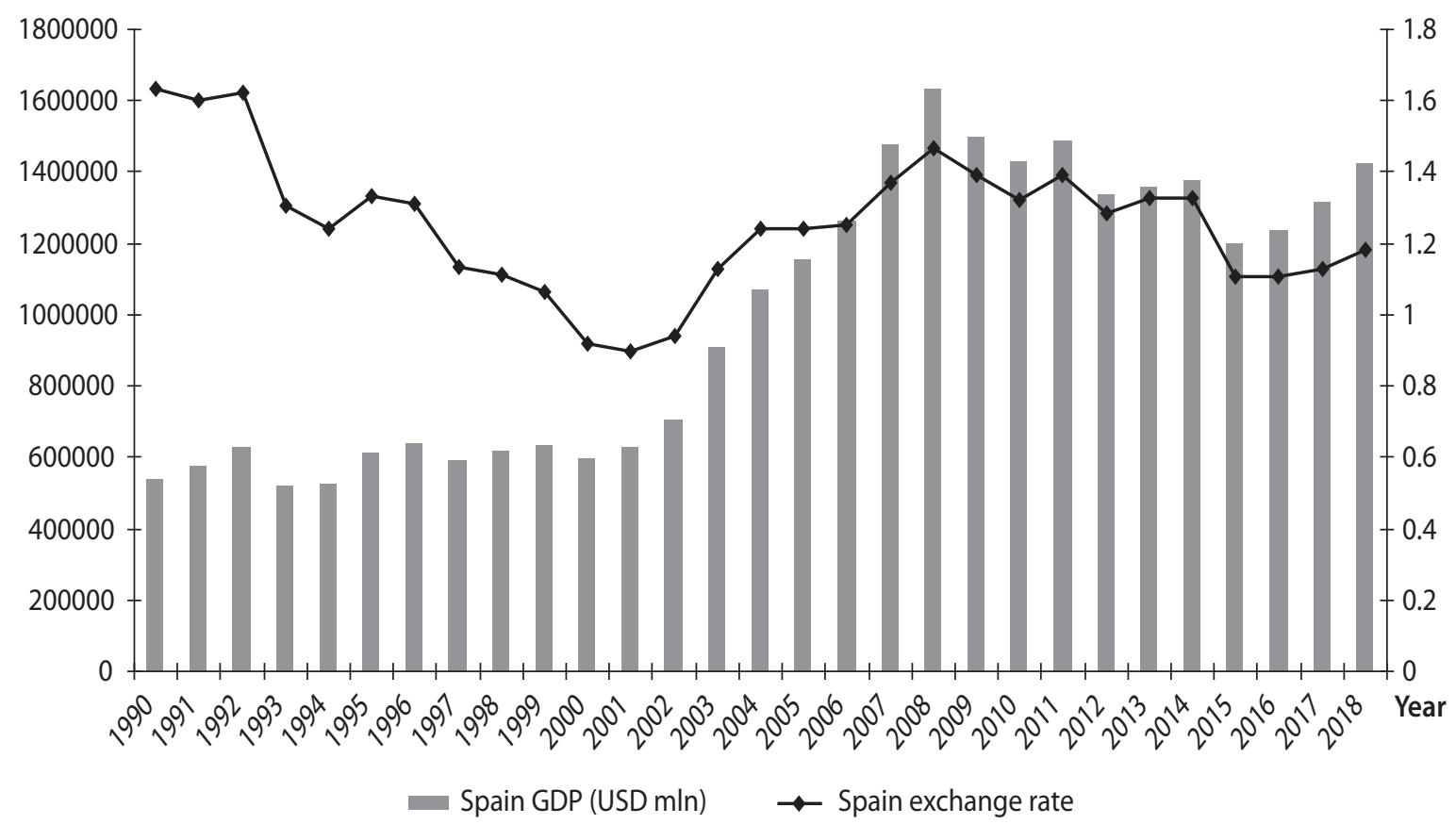

Fig. 2. GDP of Greece and the national currency exchange rate to the US dollar 1990-2018 (USD mln) [13]

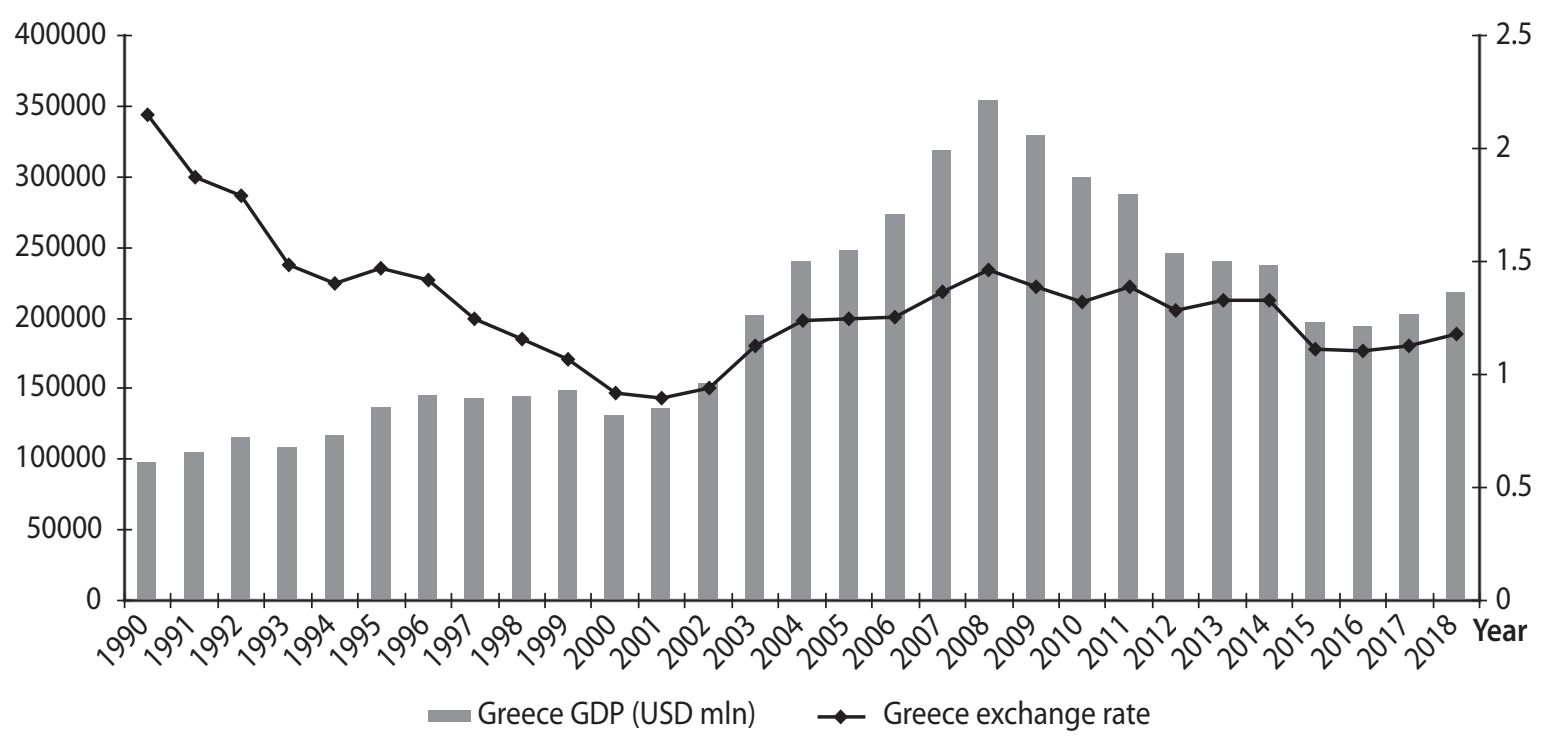

Fig. 3. GDP of Spain and the national currency exchange rate to the US dollar 1990-2018 (USD mln) [13]

Greece and Spain, it is possible to see a significant correlation between the inflow and the outflow of FDI in the countries under study (Fig. 4, Fig. 5).

The single monetary policy pursued by the European Central Bank at the present stage is contradictory and vulnerable, confirming the significant differentiation in the levels of development of EU and eurozone countries, as well as their failure to comply with the basic requirements of budgetary discipline.

The imperfection of the single monetary policy was clearly demonstrated in the context of the EU debt crisis, when countries started resorting to large-scale borrowing to cover budget deficits. The latter, by increasing the share of government debt in gross domestic product (GDP) above the Maastricht criterion (60\%), led to a de- crease in sovereign ratings, which, in turn, led to an increase in government bond yields and a growth in the value of loans to national companies.

7 he European Central Bank's monetary policy is implemented to maintain price stability in the euro area. To achieve this objective, the ECB sets interest rates on transactions with European banks and applies other instruments within anti-crisis policy program. The European Central Bank uses a corridor system of interest rates. Corridor boundaries set interest rates on constantly available transactions. Interest rates on the main refinancing operations - short-term (7 days) open market operations, are formed within this corridor. The auctions can be held with variable or fixed rates. From 


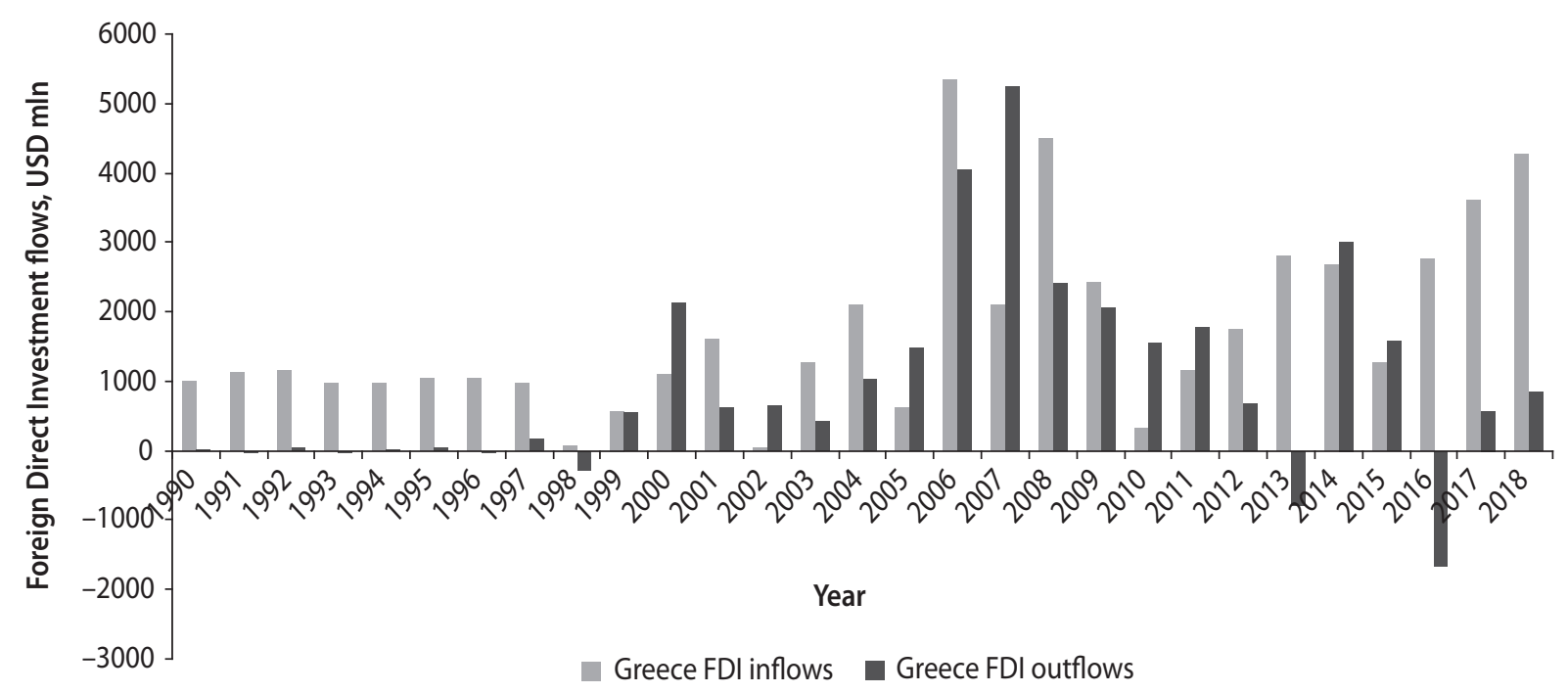

Fig. 4. Foreign Direct Investment flows in the Greek economy 1990-2018 (USD mln) [13]

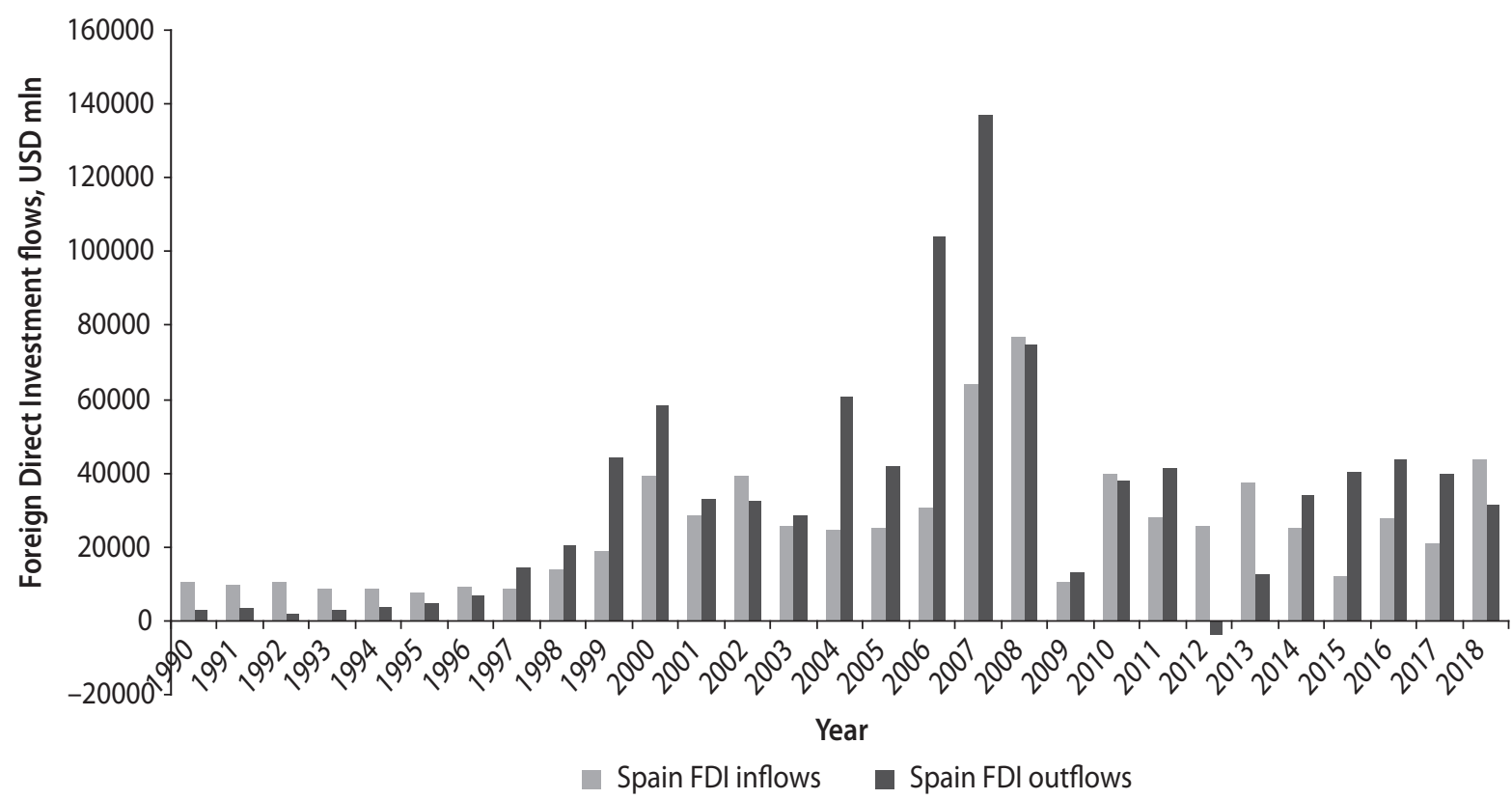

Fig. 5. Foreign Direct Investment flows in the Spanish economy 1990-2018 (USD mln) [13]

November 2008, the ECB conducts fixed-rate auction operations. This interest rate is the refinancing rate. The main refinancing operations are used to manage shortterm rates. The European Central Bank also conducts long-term open market refinancing (LTRO) operations, with interest rates based on the refinancing rate.

T order to achieve the ECB's objectives of stabilizing prices and influencing market interest rates in the Leuro area, a program for the purchase of assets (public and private securities) was launched. Interest rates set by the ECB have reached very low levels and therefore the regulator has to use non-standard instruments [12].

The economy of Spain is classified as a Southern European variety of the Western European socio-economic model. When joining the EU, it was characterized by a direct and active state intervention in the economy and production; widespread family and cooperative ownership; high levels of concentration of capital and production at the upper level of the production structure, with its extreme allocation at the lower level, where small enterprises play a major role.

With the entry of Spain into the Eurozone, due to the reduction of currency risks and the use of the ECB's low interest rate, which was determined using the Harmonized Index of Consumer Prices, the availability of credit resources increased. This has contributed to the country's economic growth.

Spain's participation in programs of EU Structural Funds has become an important driver of its economic development. The country was one of the main beneficiaries of these programs, which provided its economy with the inflow of more than EUR183 billion (excluding the funds for implementation of the Common Agricultural 
Policy) during the period 1989-2017. These programs helped develop depressive regions of Spain by creating infrastructure facilities, improving the quality of financial services, enhancing their innovation capacity, and internationalizing businesses. At the same time, the number of regions whose GDP per capita is less than $75 \%$ of the EU average decreased from 13th to 6th.

The current position of Greece in the world economy results from a number of internal problems conditioned by peculiarities of the economic model of its development, which is aggravated by the restrictions imposed on the country as a eurozone member. Greece has received almost EUR290 billion from the eurozone and the International Monetary Fund (IMF) since 2010. Despite completing the financial assistance program, Greece needs to continue to fulfill its obligations to international lenders. In June 2019, they achieved a mutual agreement on reducing the debt load upon condition of the country's maintaining a primary budget surplus of $3.5 \%$ until 2022. If Greece does not fulfill its promise, the conditions for debt restructuring can be changed [12].

\section{CONCLUSIONS}

Therefore, the article outlines the main factors affecting the financial system, as well as their impact on the economies of Greece and Spain. These issues require further research and thorough consideration to show the impact of all micro- and macro-financial factors on the national economy in order to build a dynamic model.

Similarly, it is important to carry out a more detailed study of the impact of financial market volatility on economic growth, and, at the micro-level, it is necessary to consider in more details the peculiarities of the interaction of financial institutions with other economic agents.

\section{LITERATURE}

1. Demirguc-Kunt A., Levin R. Bank-Based and Market-Based Financial Systems: Cross-Country Comparisons. World Bank Policy Working Paper. July 1999. No. 2143. URL: https://papers.ssrn.com/sol3/papers. cfm?abstract_id $=569255$

2. Paun C. V., Musetescu R. C., Topan V. M. and Danuletiu D. C. The Impact of Financial Sector Development and Sophistication on Sustainable Economic Growth. Sustainability. 2019. Vol. 11. Issue 6. P. 1-21. DOI: 10.3390/su11061713

3. Hugh P. Financial Development and Economic Growth in Underdeveloped Countries. Economic Development and Cultural Change. 1966. Vol. 14. No. 2. P. 174-189. URL: https://www.jstor.org/stable/1152568?seq=1

4. Blanco L. The Finance-Growth Link in Latin America. Southern Economic Journal. 2009. Vol. 76. No. 1. P. 224-248. URL: https://www.jstor.org/stable/ 27751461 ?seq $=1$

5. Ergungor O. E. Financial system structure and economic growth: Structure matters. International Review of
Economics \& Finance. 2008. Vol. 17. Issue 2. P. 292-305. DOI: https://doi.org/10.1016/j.iref.2006.09.001

6. Gambacorta L., Yang J., Tsatsaronis K. Financial structure and growth. BIS Quarterly Review. March 2014. P. 21-35. URL: https://www.bis.org/publ/qtrpdf/r_ qt1403e.pdf

7. Guei K. M. A. Does financial structure matter for economic growth: An evidence from South Africa. MPRA. December 2018. URL: https://mpra.ub.unimuenchen. de/92823/1/MPRA_paper_92823.pdf

8. Lomachynska I., Yakubovskiy S., Plets I. Dynamics of Austrian foreign direct investment and their influence on the national economy. Baltic Journal of Economic Studies. 2018. Vol. 4. No. 5. P. 167-174.

DOI: http://dx.doi.org/10.30525/2256-0742/2018-4-5167-174.

9. Yakubovskiy S., Rodionova T., Derkach T. Impact of Foreign Investment Income on External Positions of Emerging Markets Economies. Journal Transition Studies Review. 2019. Vol. 26. No 1. P. 81-91. DOI: https://doi.org/10.14665/1614-4007-26-1-005

10. European Central Bank. Annual Report 2018. URL: https://www.ecb.europa.eu/pub/pdf/annrep/ ar2018 d08cb4c623.en.pdf

11. Gadanecz B., Jayaram K. Measures of financial stability - a review. URL: https://www.bis.org/ifc/publ/ifcb31ab.pdf

12. European Central Bank. Financial Stability Review. November 2019. URL: https://www.ecb.europa.eu/pub/ pdf/fsr/ecb.fsr201911 facad0251f.en.pdf

13. UNCTAD Statistics. URL: https://unctad.org/en/Pages/ statistics.aspx

\section{REFERENCES}

Blanco, L. "The Finance-Growth Link in Latin America". Southern Economic Journal. 2009. https://www.jstor. org/stable/27751461?seq=1

Demirguc-Kunt, A., and Levin, R. "Bank-Based and MarketBased Financial Systems: Cross-Country Comparisons". World Bank Policy Working Paper. July 1999. https://papers.ssrn.com/sol3/papers.cfm?abstract_id=569255

"European Central Bank. Annual Report 2018". https://www. ecb.europa.eu/pub/pdf/annrep/ar2018 d08cb4c623. en.pdf

"European Central Bank. Financial Stability Review". November 2019. https://www.ecb.europa.eu/pub/pdf/ fsr/ecb.fsr201911 facad0251f.en.pdf

Ergungor, O. E. "Financial system structure and economic growth: Structure matters". International Review of Economics \& Finance, vol. 17, no. 2 (2008): 292-305. DOl: https://doi.org/10.1016/j.iref.2006.09.001

Gadanecz, B., and Jayaram, K. "Measures of financial stability - a review". https://www.bis.org/ifc/publ/ifcb31ab. pdf

Gambacorta, L., Yang, J., and Tsatsaronis, K. "Financial structure and growth". BIS Quarterly Review. March 2014. https://www.bis.org/publ/qtrpdf/r_qt1403e.pdf

Guei, K. M. A. "Does financial structure matter for economic growth: An evidence from South Africa". MPRA. December 2018. https://mpra.ub.unimuenchen.de/ 92823/1/MPRA_paper_92823.pdf 
Hugh, P. "Financial Development and Economic Growth in Underdeveloped Countries". Economic Development and Cultural Change. 1966. https://www.jstor.org/ stable $/ 1152568$ ?seq $=1$

Lomachynska, I., Yakubovskiy, S., and Plets, I. “Dynamics of Austrian foreign direct investment and their influence on the national economy". Baltic Journal of Economic Studies, vol. 4, no. 5 (2018): 167-174.

DOI: http://dx.doi.org/10.30525/2256-0742/2018-4-5167-174
Paun, C. V. et al. "The Impact of Financial Sector Development and Sophistication on Sustainable Economic Growth". Sustainability, vol. 11, no. 6 (2019): 1-21. DOI: $10.3390 /$ su 11061713

UNCTAD Statistics. https://unctad.org/en/Pages/statistics. aspx

Yakubovskiy, S., Rodionova, T., and Derkach, T. "Impact of Foreign Investment Income on External Positions of Emerging Markets Economies". Journal Transition Studies Review, vol. 26, no. 1 (2019): 81-91. DOI: https://doi.org/10.14665/1614-4007-26-1-005

\title{
ЕНДОГЕНІЗАЦІЯ ЕКОНОМІЧНОГО РОЗВИТКУ ЧЕРЕЗ РОЗБУДОВУ ВИСОКОТЕХНОЛОГІЧНИХ ФАРМАЦЕВТИЧНИХ ВИРОБНИЦТВ: ДОСВІД ЕВРОПИ, УРОКИ ДЛЯ УКРАЇНИ
}

\author{
О2020 САЛІХОВА О. Б., ГОНЧАРЕНКО Д. 0.
}

\author{
УДК 330.341:336.5:338.45 \\ JEL: L52; L65; 014; 032
}

\section{Саліхова О.Б., Гончаренко Д. О. Ендогенізація економічного розвитку через розбудову високотехнологічних фармацевтичних виробництв: досвід Європи, уроки для України}

Розбудова національних фармацевтичних виробництв - це не лише вирішення питання здоров'я нації, зниження навантаження на пенсійні системи та системи медичного обслуговування, а й збереження існуючої зайнятості та започаткування нових робочих місць, науковий та інноваційний розвиток, зменшення залежності від імпорту, створення високої доданої вартості та прискорення економічного зростання. Метою статті є узагальнення особливостей форм та інструментів державної допомоги компаніям фармацевтичній індустрії в Європі, обгрунтування можливості імплементації кращих практик в Україні та визначення ключових орієнтирів державної політики щодо інноваційного розвитку національних виробників фармацевтичної продукиії та зменшення впливу екзогенних факторів на економічне зростання. Встановлено, що виробники фармацевтичної продукції в країнах ЄС отримують фінансову допомогу здебільшого через регіональні та горизонтальні механізми, які уряди країн застосовують у контексті визначених на начіональному рівні технологічних, інноваційних і промислових пріоритетів. Обгрунтовано, що одним із найбільш розповсюджених горизонтальних механізмів сприяння розбудові фармацевтичних виробниитв в $\in C \in$ допомога господарюючим суб'єктам на дослідження, розробки та інновації. Розглянуто систему публічних закупівель як один із інструментів підтримки та захисту національних фармацевтичних виробників. Надано рекомендації для України, реалізація яких дозволить прискорити ендогенізацію економічного розвитку через розбудову національних високотехнологічних фармацевтичних виробництв і суміжних секторів економіки.

Ключові слова: державна допомога, публічні закупівлі, інновації, фармацевтичне виробництво, розвиток.

DOI: https://doi.org/10.32983/2222-4459-2020-2-49-56

Бібл.: 27.

Саліхова Олена Борисівна - доктор економічних наук, провідний науковий співробітник відділу моделювання та прогнозування економічного розвитку, Інститут економіки та прогнозування НАН України (вул. Панаса Мирного, 26, Київ, 01011, Україна)

E-mail: salikhova elena@ukr.net

ORCID: https://orcid.org/0000-0002-7669-6601

Гончаренко Дар'я Олегівна - головний спеціаліст відділу базових галузей головного управління галузей промисловості директорату промисловоі політики та стимулювання розвитку регіонів, Міністерство розвитку економіки, торгівлі та сільського господарства України (вул. М. Грушевського, 12/2, Київ, 01008, Україна)

E-mail:dp170292ddo@gmail.com

ORCID: http://orcid.org/0000-0003-4937-2596

УДК 330.341:336.5:338.45

JEL: L52; L65; 014; 032

Салихова Е. Б., Гончаренко Д. О. Эндогенизация экономического развития через развитие высокотехнологичных фармацевтических производств: опыт Европы, уроки для Украины

Развитие национальных фармацевтических производств - это не только решение вопроса здоровья нации, снижение нагрузки на пенсионные системы и системы медицинского обслуживания, но и сохранение существующей занятости и появление новых рабочих мест, научное и инновационное развитие, уменьшение зависимости от импорта, создание высокой добавленной стоимости и ускорение экономического роста. Целью статьи является обобщение особенностей форм и инструментов государственной помощи компаниям фармацевтической индустрии в Европе, обоснование возможности имплементации лучших практик в Украине и определение ключевых ориентиров государственной политики по инновационному развитию национальных производителей фармацевтической продукции и уменьшению влияния экзогенных факторов на экономический рост. Установлено, что производители фармацевтической продукции в странах ЕС получают финансовую помощь в основном через региональные и горизонтальные механизмы, которые правительства стран применяют в контексте определенных на национальном уровне технологических, инновационных и промышленных приоритетов. Обосновано, что одним из самых распространенных горизонтальных механизмов содействия развитию фармацевтических производств в ЕС является помощь хозяйствующим субъектам на исследования, разработки и инновации. Рассмотрена система публичных закупок как один из инструментов поддержки и защиты фармацевтических производителей. Даны рекомендации для Украины, реализация которых позволит ускорить эндогенизацию экономического развития посредством развития наииональных высокотехнологичных фармачевтических производств и смежных секторов экономики. 